\title{
Effect of Plant Growth Regulators and Micronutrients on Fruit Growth Characters of Kinnow Mandarin (Citrus reticulata Blanco)
}

\author{
Upendar Kumar Bagri ${ }^{1}$, R. S. Singh ${ }^{2}$, Manju Verma ${ }^{1}$, Vimal Nagar ${ }^{1 *}$ and P. K. Yadav ${ }^{1}$ \\ ${ }^{1}$ Department of Horticulture, College of Agriculture, S.K.R.A.U., \\ Bikaner-334006, Rajasthan, India \\ ${ }^{2}$ Principal Scientist, Central Institute of Arid Horticulture, Bikaner-334006, Rajasthan, India \\ *Corresponding author
}

\section{A B S T R A C T}

Keywords

Kinnow mandarin, Foliar spray, Plant growth regulators, Micronutrients

Article Info

Accepted:

12 March 2021

Available Online:

10 April 2021
The experiment was carried out on Kinnow mandarin (Citrus reticulata Blanco.)" to see the "Effect of foliar spray of plant growth regulators and micro nutrients. The experiment was laid out in Randomized Block Design (RBD) having 15 treatments with three replications each. Foliar application of plant growth regulators and micro nutrients viz. NAA (20 \& $40 \mathrm{ppm}), 2,4-\mathrm{D}$ (10 \& $20 \mathrm{ppm})$, Zinc sulphate $(0.5 \%)$, Borax $(0.5 \%)$ alone and in combinations were applied twice in the month of April and May on 14 years old Kinnow trees. The fruit growth characters like fruit weight, length, breadth, volume of fruit and fruit retention were recorded at monthly intervals and maximum fruit growth was observed with treatment $20 \mathrm{ppm} \mathrm{NAA}+\mathrm{ZnSO}_{4}$ $0.5 \%$ followed by $2,4-\mathrm{D} 10 \mathrm{ppm}+0.5 \% \mathrm{ZnSO}_{4}$. The per cent fruit drop was minimum in $10 \mathrm{ppm}$ 2,4-D treatment. However, maximum dropping of fruits were observed under control $(6.44 \%)$ recorded at final stage of study. The number of days taken for fruit maturity was higher in control (179.33) than other treatments while it was minimum under 2,4-D 20 ppm (170.12) followed by NAA $20 \mathrm{ppm}+$ Borax $0.5 \%$.

\section{Introduction}

In India Citrus fruits have a prominent place among popular fruits and being extensively grown under tropical and subtropical conditions. Among the various Citrus species, mandarin, sweet orange and lime are the common fruits having 50, 21 and 15 per cent of total area under cultivation, respectively. Mandarin (Citrus reticulata Blanco) is considered to be one of the most important cultivated species among Citrus and is being commercially grown in specific regions of the country, like "Nagpur mandarin" in Central India, "Khasi mandarin" in North Eastern regions and "Coorg mandarin" in Southern 
States of Karnataka (Coorg, Chikmangaloor, Hassan), Kerala (Wyanad), Tamil Nadu (Shevray Hills, Lower Palani Hills) and Kinnow mandarin in North-Western India. Mandarin juice is refreshing and nutritious due to its ascorbic acid content, sweet - acid taste and appealing colour. Kinnow (Citrus reticulata Blanco), a mandarin hybrid belongs to the family Rutaceae and sub- family Aurantoideae. It is a potential Citrus fruit plant of irrigated semi-arid and arid region of the country. Kinnow is hybrid between King orange (Citrus nobilis Lour) and WilliowLeaf mandarin (Citrus deliciosa Tenore).

Citrus is the third most important fruit crop after mango and banana in area and production in the world. In Rajasthan, the total area under Kinnow cultivation is about 14,890 $\mathrm{ha}^{-1}$ with production 2,51,200 metric tonnes (Anon., 2016). For Kinnow, Sri-Ganganagar district is on prime position with area and production followed by Hanumangarh and Bikaner district of North-West Rajasthan. Among the various Citrus species (more than 162 species), Kinnow is an economically important sub-tropical fruit, which is grown almost all over the arid and semi-arid regions of India. In view of its prolific bearing quality coupled with relative tolerance to disease and pests, Kinnow has gained popularity amongst the growers and now it is commercially cultivated in Punjab, Haryana, Himachal Pradesh, Jammu \& Kashmir and Uttar Pradesh and to some extent in the states of Karnataka and Tamil Nadu. It is one of the most important fruits because of its pleasant flavor, juicy and sour-sweet taste. It is a subacidic fruit, freshly eaten and also used for extracting commercial pectin, refreshing drink and in making cosmetics (Bose and Mitra, 1996). 'Kinnow' (Citrus nobilis Lour $\times$ Citrus deliciosa Tenora) mandarin is the most prominent citrus cultivar for large scale cultivation. Its area and production has been increasing overtime, however, its life span is decreasing due to many biotic and abiotic factors and its average life seldom exceeds 25 years. The average production is far below than other countries (Ibrahim et al., 2011).

In some countries the productive life of Citrus tree is $\mathbf{5 0}$ years and in some cases it lives 100 years or more depending upon good management practices. The plant nutrients are one of the key factors influencing the yield of fruits. Rodriguez et al., (2005) reported that the higher levels of zinc fertilizer increased the production of medium and big fruits of Valencia orange. Foliar application of zinc was positively correlated with the production of big and medium size fruits and negatively correlated with the production of small fruits. Besides the major nutrients (NPK) and secondary elements $(\mathrm{Ca}, \mathrm{Mg}$ and $\mathrm{S})$, essential micronutrients also play a vital role to increase the plant growth and fruit growth.

The soils of arid region are mostly deficient in several nutrients, which are essential for growth and development of plant and ultimately to increase the fruit production. The availability of micronutrients from the soils is also a limiting factor in arid region due to hard pan/concretion of calcium carbonate $\left(\mathrm{CaCO}_{3}\right)$ in subsoil.

The symptoms of deficiency of some micronutrients are common in orchards, which directly or indirectly affect the fruit production. In such conditions, to save the large quantity of chemical and easy availability, foliar feeding of micronutrients is the best and easy method. However very limited information is available on the response of plant growth regulators and micronutrients on fruit plants particularly in arid ecosystem of western Rajasthan. Therefore, it seems essential to standardize the concentration of growth regulators and micronutrients in Kinnow mandarin under arid ecosystem of western Rajasthan. 


\section{Materials and Methods}

A field experiment entitled "Effect of foliar spray of plant growth regulators and micronutrients on fruit growth, yield and quality of kinnow mandarin" was carried out at ICAR- Central Institute for Arid Horticulture Bikaner (Rajasthan) and Department of Horticulture, College of Agriculture, Swami Keshwan and Rajasthan Agricultural University, Bikaner during 201617.

\section{Layout of Experiment}

Forty five plants of Kinnow mandarin having uniform size, vigour and of bearing stages at 14 years age were selected for the investigation. A single tree was kept as one replicate in a unit for each treatment. There were 15 treatments in the study having three replications. All experimental plants were maintained with common cultural practices during the course of study. The orchard was irrigated through drip irrigation.

Table.1 Details of treatments and their symbol

\begin{tabular}{|c|l|c|}
\hline S.No & Treatments & Symbol \\
\hline $\mathbf{1}$ & Control(Water spray) & $\mathrm{T}_{0}$ \\
\hline $\mathbf{2}$ & NAA 20 ppm & $\mathrm{T}_{1}$ \\
\hline $\mathbf{3}$ & NAA 40 ppm & $\mathrm{T}_{2}$ \\
\hline $\mathbf{4}$ & $2,4-\mathrm{D} 10 \mathrm{ppm}$ & $\mathrm{T}_{3}$ \\
\hline $\mathbf{5}$ & $2,4-\mathrm{D} \quad 20 \mathrm{ppm}$ & $\mathrm{T}_{4}$ \\
\hline $\mathbf{6}$ & $\mathrm{ZnSO}_{4} \quad 0.5 \%$ & $\mathrm{~T}_{5}$ \\
\hline $\mathbf{7}$ & Borax $0.5 \%$ & $\mathrm{~T}_{6}$ \\
\hline $\mathbf{8}$ & NAA 20ppm $+\mathrm{ZnSO}_{4} 0.5 \%$ & $\mathrm{~T}_{7}$ \\
\hline $\mathbf{9}$ & NAA 40ppm $+\mathrm{ZnSO}_{4} 0.5 \%$ & $\mathrm{~T}_{8}$ \\
\hline $\mathbf{1 0}$ & 2,4-D 10ppm + ZnSO $0.5 \%$ & $\mathrm{~T}_{9}$ \\
\hline $\mathbf{1 1}$ & 2,4-D 20ppm + ZnSO $0.5 \%$ & $\mathrm{~T}_{10}$ \\
\hline $\mathbf{1 2}$ & NAA 20ppm + Borax 0.5\% & $\mathrm{T}_{11}$ \\
\hline $\mathbf{1 3}$ & NAA 40ppm + Borax 0.5\% & $\mathrm{T}_{12}$ \\
\hline $\mathbf{1 4}$ & 2,4-D 10ppm + Borax 0.5\% & $\mathrm{T}_{13}$ \\
\hline $\mathbf{1 5}$ & 2,4-D 20ppm + Borax 0.5\% & $\mathrm{T}_{14}$ \\
\hline
\end{tabular}

\section{Application of the micronutrient}

The micronutrients $v i z$, Zinc (Zn) applied as foliar spray through their sulphate salt. The concentration of $\mathrm{Zn}$ and boron were used $0.50 \%$ and $0.50 \%$, respectively. In order to check the burning effect of nutrient salt, hydrate lime was added in all treatments solution.

The amount of lime was used half the amount by weight of the nutrient salt in the solution. eepol $(0.1 \%)$ was used to get proper sticking of the solution on the foliage for spray. PGR solutions were prepared on the day of application of treatment. All the 45 trees were sprayed according to treatments with help of the sprayer. The first spray was done in first week of April, 2016, followed by second spray after a month interval.

\section{Results and Discussion}

Effect of Plant Growth Regulators and Micronutrients on fruit growth at monthly intervals from pea stage till harvest

For fruit growth, data on weight, length, breadth and volume of fruits were recorded at 
monthly intervals after imposing treatments till fruit maturity for harvest.

\section{Fruit weight (g)}

Fruit weight recorded at monthly interval from the month of May to November, 2016, which is in response to foliar sprays of growth regulators, micronutrients and their combinations. Fast growth and development in fruit was noticed from May to September month. The minimum fruit weight was recorded at the beginning of this study i.e. during the May, 2016. The higher weight of fruit was recorded during the month of November i.e. maturity stage.

The higher fruit weight were registered with foliar feeding of NAA 20ppm + Zinc sulphate $0.5 \% \mathrm{~T}_{7} \quad(131.12 \mathrm{~g})$, followed by 2,4-d $10 \mathrm{ppm}+\mathrm{Zn} \quad 0.5 \%, \quad \mathrm{~T}_{9} \quad(130.95 \mathrm{~g})$ and the minimum fruit weight was recorded in $\mathrm{T}_{0}$ (94.11g). However, the treatments $\mathrm{T}_{8}, \mathrm{~T}_{10}, \mathrm{~T}_{11}$ $\mathrm{T}_{13}$ and $\mathrm{T}_{14}$ were at par and significantly superior with control (water spray). However, treatment $\mathrm{T}_{3}, \mathrm{~T}_{4}, \mathrm{~T}_{5}$ and, $\mathrm{T}_{6}$ were significantly better than control in terms of weight of fruits. The treatment effect of $T_{1}$ and $T_{2}$ were at par with control.

\section{Length of fruit (cm)}

The difference in length in fruits at monthly interval from the month of May to November 2016, which is in response to various sprays of growth regulators, micronutrients and their combinations, showed a significant increase in length of fruits with the passage of time. The minimum length of fruit was recorded at the beginning of this study i.e. during the May, 2016. A progressive increase was recorded in length of Kinnow fruits in the subsequent months. The highest length of fruits was recorded during the month of November.

At the end of the study, the variation in length of fruit was significant. Among the different treatments, the maximum length of fruit was recorded in $\mathrm{T}_{7}$ (NAA $20 \mathrm{ppm}+\mathrm{ZnSO}_{4} 0.5 \%$ ) $(6.66 \mathrm{~cm})$ followed by $T_{1}(6.50 \mathrm{~cm})$ and $T_{3}$ $(6.46 \mathrm{~cm})$, while the minimum length of fruit was recorded in $\mathrm{T}_{8}(6.10 \mathrm{~cm})$. The application of NAA $20 \mathrm{ppm}+\mathrm{ZnSO}_{4} 0.5 \%(6.66 \mathrm{~cm})$ was gave better results in terms of length of fruit followed by $T_{1}(6.50 \mathrm{~cm})$. However, the control fruits were found to be of $5.39 \mathrm{~cm}$, while all the treatments were at par with each other.

\section{Breadth of fruit (cm)}

The changes of fruit breadth at monthly interval from the month of May to November 2016, which is in response to various sprays of growth regulators, micronutrients and their combinations, noted a significant increase in breadth of fruits with the passage of time. The minimum breadth of fruits was recorded at the beginning of this study i.e. during the May, 2016. The highest breadth of fruits was recorded during the month of November. At the end of the study, among the different treatments, the maximum breadth of fruit was recorded in $T_{2}(6.85 \mathrm{~cm})$ followed by $\mathrm{T}_{3}(6.71$ $\mathrm{cm})$ and $\mathrm{T}_{6}$, while the minimum breadth of fruit was recorded in control $(5.69 \mathrm{~cm})$. All the treatments were at par each other.

\section{Volume of fruit (cc)}

The changes of volume of fruits at monthly interval from the month of May to November 2016 which is in response to various sprays of growth regulators, micronutrients and their combinations, observed a significant increase in volume of fruits with the passage of time. The minimum volume of fruits was recorded at the beginning of this study i.e. during the May, 2016 while the highest volume of fruits was recorded during the month of November.

At the end of the growth study, among the different treatments, the maximum volume of fruits was recorded in $\mathrm{T}_{7}(6.83 \mathrm{cc})$ followed by 
$\mathrm{T}_{3}(6.68 \mathrm{cc})$ and $\mathrm{T}_{12}$. The treatment with micronutrients was found beneficial in improving volume of fruit The minimum volume of fruit was recorded in control (5.25 cc), while all the treatments were at par to each other. Foliar spray of NAA $20 \mathrm{ppm}+$ $\mathrm{ZnSO}_{4} \quad 0.5 \%$ treatment was superior over control in terms of volume of fruit.

\section{Fruit drop (\%)}

The changes of fruit drop at monthly interval from the month of May to November 2016, which is in response to various sprays of growth regulators, micronutrients and their combinations, showed a significant decrease in drop of fruit with the passage of time. The heavy dropping in fruits was recorded during the month of May and June. The maximum per cent fruit drop of was recorded at the beginning of this study i.e. during the May, 2016.

The lowest fruit drop was recorded during the month of October-November and difference in per cent fruit drop was significant among the treatments during the period of study except during the September month.

At the end of the experiment, among the different treatments, the maximum drop of fruit at final stage during the month of November was recorded in control $\mathrm{T}_{0}(6.44 \%)$ followed by $\mathrm{T}_{1}$. The minimum fruit drop was recorded in $\mathrm{T}_{3}, 2-4 \mathrm{D} 10 \mathrm{ppm}(1.11 \%)$, while all the treatments were at par with each other. It is clear from data that foliar spray of auxins were found effective to reduce fruit drop in Kinnow.

\section{Fruit retention (\%)}

The fruit retention is beneficial parameters with respect to yield attributes in Kinnow. All the treatments including control showed a gradual increase in fruit retention over the period of time. The minimum fruit retention was recorded at the beginning of this study i.e. during the May, 2016. A progressive increase was recorded in retention of Kinnow fruits in subsequent months. The highest fruit retention was recorded during the month of November. At the end of the experiment, among the different treatments, the maximum retention of fruit was recorded in $\mathrm{T}_{3}(98.89 \%)$ followed by $\mathrm{T} 9, \mathrm{~T} 4$ and $\mathrm{T}_{7}(98.48 \%)$. The minimum fruit retention was recorded in control (93.56), while all the treatments were at par with each other.

\section{Fruit growth at monthly intervals}

The results indicated that foliar application of zinc, boron and NAA, 2,4-D alone and its combinations improved the fruit growth at monthly interval from pea stage till harvest in terms of fruit weight, length of fruit, breadth of fruit and volume of fruit. The per cent fruit drop and retention (\%) in Kinnow fruit was also observed to be improved in different treatments in comparison to control (water spray).

Application of plant growth regulators and micronutrients had significantly increased the fruit weight, length and breadth of fruit and volume of fruit over control during growth period. It is also clear that fast growth and development in fruit were noticed from May to September month. The fruit weight increased significantly with the passage of time. During the month of May, there was no significant difference among treatments in fruit weight. However, in the month of November, the maximum average fruit weight was recorded in $\mathrm{T}_{7}\left(131.12 \mathrm{~g}\right.$ ) followed by $\mathrm{T}_{9}$ $(130.95 \mathrm{~g})$. However, in control average fruit weight was recorded (94.11g.).

In the present study, among the different treatments, the fruit weight was less under $T_{2}$ $(96.32 \mathrm{~g})$. However, the treatment effect was superior over control in terms of average weight of fruit during fruit growth period after spray treatments. 
Table.2 Effect of foliar spray of plant growth regulators and micronutrients (NAA, 2,4-D, Zn \& B) on fruit weight (g) at monthly intervals from pea stage till harvest

\begin{tabular}{|c|c|c|c|c|c|c|c|c|}
\hline Symbols & Treatments & May 16 & June 16 & July 16 & Aug 16 & Sept 16 & Oct 16 & Nov 16 \\
\hline $\mathbf{T}_{\mathbf{0}}$ & Control (water spray) & 2.50 & 4.47 & 25.95 & 60.49 & 80.31 & 92.63 & 94.11 \\
\hline $\mathbf{T}_{1}$ & NAA $20 \mathrm{ppm}$ & 2.76 & 5.64 & 27.51 & 57.63 & 84.33 & 95.25 & 98.39 \\
\hline $\mathbf{T}_{2}$ & NAA $40 \mathrm{ppm}$ & 2.55 & 5.24 & 27.47 & 59.81 & 84.10 & 94.63 & 96.32 \\
\hline $\mathbf{T}_{3}$ & 2,4-D $10 \mathrm{ppm}$ & 2.30 & 4.71 & 26.53 & 59.71 & 86.12 & 106.98 & 112.25 \\
\hline $\mathbf{T}_{4}$ & 2,4-D $20 \mathrm{ppm}$ & 1.81 & 5.33 & 26.35 & 57.22 & 83.15 & 104.98 & 111.05 \\
\hline $\mathbf{T}_{5}$ & $\mathrm{ZnSO}_{4} 0.5 \%$ & 2.43 & 5.60 & 24.91 & 55.16 & 85.45 & 113.58 & 119.15 \\
\hline $\mathbf{T}_{6}$ & Borax $0.5 \%$ & 2.25 & 6.21 & 24.67 & 66.46 & 95.21 & 116.15 & 121.38 \\
\hline $\mathbf{T}_{7}$ & $\mathrm{NAA} 20 \mathrm{ppm}+\mathrm{ZnSO}_{4} 0.5 \%$ & 2.00 & 5.49 & 29.69 & 55.73 & 98.28 & 123.01 & 131.12 \\
\hline $\mathbf{T}_{8}$ & $\mathrm{NAA} 40 \mathrm{ppm}+\mathrm{ZnSO}_{4} 0.5 \%$ & 2.01 & 5.37 & 25.67 & 61.46 & 96.55 & 112.76 & 123.19 \\
\hline $\mathbf{T}_{9}$ & 2,4-D $10 \mathrm{ppm}+\mathrm{ZnSO}_{4} 0.5 \%$ & 2.13 & 5.44 & 31.01 & 67.28 & 90.95 & 118.34 & 130.95 \\
\hline $\mathbf{T}_{10}$ & 2,4-D $20 \mathrm{ppm}+\mathrm{ZnSO}_{4} 0.5 \%$ & 1.97 & 5.20 & 25.08 & 55.45 & 92.45 & 117.64 & 124.94 \\
\hline $\mathbf{T}_{11}$ & NAA $20 \mathrm{ppm}+$ Borax $0.5 \%$ & 1.75 & 4.43 & 23.70 & 49.40 & 85.18 & 120.43 & 128.10 \\
\hline $\mathbf{T}_{12}$ & NAA $40 \mathrm{ppm}+$ Borax $0.5 \%$ & 2.54 & 5.35 & 23.81 & 47.42 & 84.80 & 114.39 & 127.21 \\
\hline $\mathbf{T}_{13}$ & 2,4-D 10 ppm + Borax 0.5\% & 2.14 & 4.84 & 25.80 & 49.74 & 91.54 & 118.32 & 126.40 \\
\hline \multirow[t]{3}{*}{$\mathbf{T}_{14}$} & 2,4-D 20 ppm + Borax 0.5\% & 2.09 & 5.28 & 28.37 & 56.53 & 95.31 & 115.06 & 123.35 \\
\hline & S.Em. \pm & 0.22 & 0.14 & 1.28 & 2.36 & 2.83 & 1.59 & 1.30 \\
\hline & $\mathrm{CD}$ at $5 \%$ & NS & 0.41 & 3.73 & 6.86 & 8.21 & 4.61 & 3.77 \\
\hline
\end{tabular}


Table.3 Effect of foliar spray of plant growth regulators and micronutrients (NAA, 2,4-D, Zn \& B) on length of fruit (cm) at monthly intervals from pea stage till harvest

\begin{tabular}{|c|c|c|c|c|c|c|c|c|}
\hline Symbols & Treatments & May 16 & June 16 & July 16 & Aug 16 & Sept 16 & Oct 16 & Nov 16 \\
\hline $\mathbf{T}_{\mathbf{0}}$ & Control (water spray) & 1.72 & 1.98 & 3.69 & 4.17 & 5.12 & 5.18 & 5.39 \\
\hline $\mathbf{T}_{1}$ & NAA 20 ppm & 1.75 & 2.24 & 3.85 & 4.86 & 5.25 & 5.63 & 6.50 \\
\hline $\mathbf{T}_{2}$ & NAA 40 ppm & 1.56 & 2.20 & 3.66 & 4.85 & 4.99 & 5.64 & 6.40 \\
\hline $\mathbf{T}_{3}$ & 2,4-D 10 ppm & 1.34 & 2.07 & 3.80 & 4.76 & 4.78 & 5.45 & 6.46 \\
\hline $\mathbf{T}_{4}$ & 2,4-D 20 ppm & 1.31 & 2.12 & 3.73 & 4.74 & 5.42 & 5.43 & 6.30 \\
\hline $\mathbf{T}_{5}$ & $\mathrm{ZnSO}_{4} 0.5 \%$ & 1.39 & 2.19 & 3.67 & 4.75 & 5.18 & 5.36 & 6.32 \\
\hline$T_{6}$ & Borax $0.5 \%$ & 1.48 & 2.28 & 3.92 & 4.84 & 5.52 & 5.65 & 6.32 \\
\hline $\mathbf{T}_{7}$ & $\mathrm{NAA} 20 \mathrm{ppm}+\mathrm{ZnSO}_{4} 0.5 \%$ & 1.37 & 2.22 & 3.85 & 4.77 & 5.50 & 5.60 & 6.66 \\
\hline $\mathbf{T}_{8}$ & $\mathrm{NAA} 40 \mathrm{ppm}+\mathrm{ZnSO}_{4} 0.5 \%$ & 1.38 & 2.14 & 3.68 & 4.81 & 5.40 & 5.48 & 6.10 \\
\hline $\mathbf{T}_{9}$ & $2,4-\mathrm{D} 10 \mathrm{ppm}+\mathrm{ZnSO}_{4} 0.5 \%$ & 1.46 & 2.05 & 3.59 & 4.72 & 5.42 & 5.47 & 6.19 \\
\hline $\mathbf{T}_{10}$ & $2,4-\mathrm{D} 20 \mathrm{ppm}+\mathrm{ZnSO}_{4} 0.5 \%$ & 1.38 & 1.19 & 3.53 & 4.79 & 5.38 & 5.40 & 6.12 \\
\hline $\mathbf{T}_{11}$ & NAA $20 \mathrm{ppm}+$ Borax $0.5 \%$ & 1.39 & 1.91 & 3.66 & 4.75 & 5.39 & 5.41 & 6.14 \\
\hline $\mathbf{T}_{12}$ & NAA 40 ppm + Borax $0.5 \%$ & 1.37 & 1.71 & 3.61 & 4.78 & 5.31 & 5.37 & 6.19 \\
\hline $\mathbf{T}_{13}$ & 2,4-D $10 \mathrm{ppm}+$ Borax $0.5 \%$ & 1.36 & 2.01 & 3.58 & 4.76 & 4.76 & 5.36 & 6.24 \\
\hline \multirow[t]{3}{*}{$\mathbf{T}_{14}$} & 2,4-D $20 \mathrm{ppm}+$ Borax $0.5 \%$ & 1.34 & 1.86 & 3.68 & 4.71 & 4.97 & 5.43 & 6.36 \\
\hline & S.Em. \pm & 0.05 & 0.08 & 0.07 & 0.06 & 0.16 & 0.08 & 0.09 \\
\hline & $\mathrm{CD}$ at $5 \%$ & 0.16 & 0.23 & 0.21 & 0.20 & 0.47 & 0.23 & 0.27 \\
\hline
\end{tabular}


Table.4 Effect of foliar spray of plant growth regulators and micronutrients (NAA, 2,4-D, Zn \& B) on breadth of fruit (cm) at monthly intervals from pea stage till harvest

\begin{tabular}{|c|c|c|c|c|c|c|c|c|}
\hline Symbols & Treatments & May 16 & June 16 & July 16 & Aug.16 & Sept.16 & Oct.16 & Nov.16 \\
\hline $\mathbf{T}_{\mathbf{0}}$ & Control (water spray) & 1.32 & 1.95 & 3.74 & 4.48 & 5.08 & 5.48 & 5.69 \\
\hline $\mathbf{T}_{1}$ & NAA 20 ppm & 1.53 & 2.23 & 3.91 & 4.50 & 5.82 & 6.35 & 6.41 \\
\hline $\mathbf{T}_{2}$ & NAA 40 ppm & 1.57 & 2.13 & 3.83 & 4.45 & 6.07 & 6.49 & 6.85 \\
\hline $\mathbf{T}_{4}$ & 2,4-D $20 \mathrm{ppm}$ & 1.38 & 2.08 & 3.97 & 4.78 & 5.72 & 6.11 & 6.53 \\
\hline $\mathbf{T}_{5}$ & $\mathrm{ZnSO}_{4} 0.5 \%$ & 1.37 & 2.23 & 3.65 & 4.81 & 6.02 & 6.45 & 6.47 \\
\hline $\mathbf{T}_{6}$ & Borax $0.5 \%$ & 1.50 & 2.31 & 3.72 & 4.98 & 6.03 & 6.58 & 6.71 \\
\hline $\mathbf{T}_{8}$ & $\mathrm{NAA} 40 \mathrm{ppm}+\mathrm{ZnSO}_{4} 0.5 \%$ & 1.41 & 2.11 & 3.80 & 4.83 & 5.47 & 6.15 & 6.25 \\
\hline $\mathbf{T}_{\mathbf{9}}$ & 2,4-D $10 \mathrm{ppm}+\mathrm{ZnSO}_{4} 0.5 \%$ & 1.45 & 2.21 & 3.95 & 4.99 & 5.34 & 6.06 & 6.29 \\
\hline $\mathbf{T}_{10}$ & $2,4-\mathrm{D} 20 \mathrm{ppm}+\mathrm{ZnSO}_{4} 0.5 \%$ & 1.44 & 2.19 & 3.69 & 4.70 & 5.66 & 6.13 & 6.50 \\
\hline $\mathbf{T}_{11}$ & NAA $20 \mathrm{ppm}+$ Borax $0.5 \%$ & 1.52 & 2.16 & 3.93 & 4.53 & 5.70 & 6.17 & 6.34 \\
\hline $\mathbf{T}_{12}$ & NAA $40 \mathrm{ppm}+$ Borax $0.5 \%$ & 1.54 & 2.14 & 3.71 & 4.49 & 5.65 & 6.36 & 6.37 \\
\hline $\mathbf{T}_{13}$ & 2,4-D $10 \mathrm{ppm}+$ Borax $0.5 \%$ & 1.46 & 2.25 & 3.76 & 4.48 & 5.40 & 6.19 & 6.36 \\
\hline
\end{tabular}


Table. 5 Effect of foliar spray of plant growth regulators and micronutrients (NAA, 2,4-D, Zn \& B) on volume of fruit (cc) at monthly intervals from pea stage till harvest

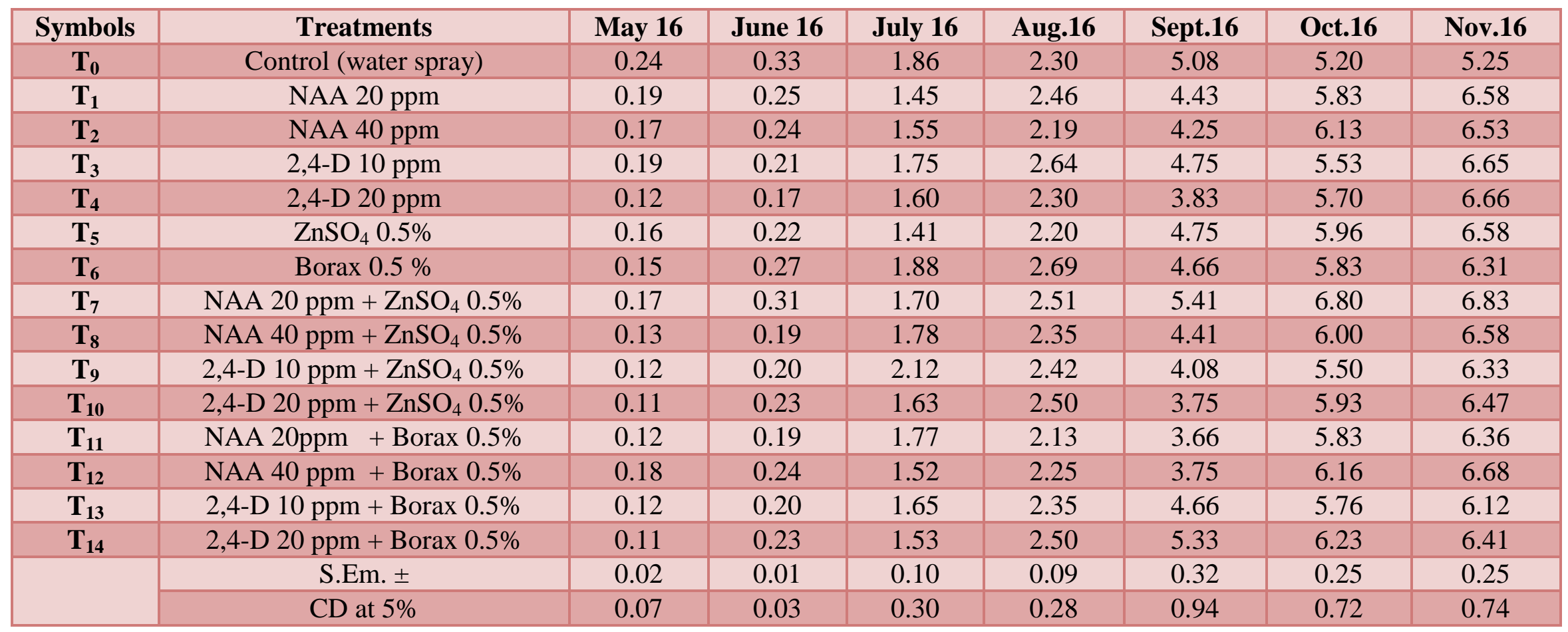


Table.6 Effect of foliar spray of plant growth regulators and micronutrients (NAA, 2,4-D, Zn \& B) on fruit drop (\%) at monthly intervals

\begin{tabular}{|c|c|c|c|c|c|c|c|c|}
\hline Symbols & Treatments & May 16 & June 16 & July 16 & Aug16 & Sept 16 & Oct 16 & Nov 16 \\
\hline $\mathbf{T}_{\mathbf{0}}$ & Control (water spray) & 29.49 & 22.97 & 16.92 & 10.97 & 8.19 & 7.16 & 6.44 \\
\hline $\mathbf{T}_{1}$ & NAA $20 \mathrm{ppm}$ & 28.53 & 26.70 & 20.02 & 12.39 & 8.99 & 4.66 & 2.44 \\
\hline $\mathbf{T}_{2}$ & NAA 40 ppm & 27.82 & 28.15 & 22.55 & 15.48 & 7.07 & 3.63 & 2.08 \\
\hline $\mathbf{T}_{4}$ & 2,4-D $20 \mathrm{ppm}$ & 23.86 & 18.75 & 16.27 & 8.89 & 6.00 & 2.22 & 1.34 \\
\hline $\mathbf{T}_{5}$ & $\mathrm{ZnSO}_{4} 0.5 \%$ & 24.33 & 19.67 & 15.51 & 9.11 & 6.08 & 2.77 & 2.18 \\
\hline $\mathbf{T}_{6}$ & Borax $0.5 \%$ & 30.76 & 28.17 & 18.43 & 8.22 & 5.12 & 1.99 & 1.99 \\
\hline $\mathbf{T}_{8}$ & $\mathrm{NAA} 40 \mathrm{ppm}+\mathrm{ZnSO}_{4} 0.5 \%$ & 25.14 & 20.85 & 16.55 & 10.98 & 6.22 & 3.11 & 1.55 \\
\hline $\mathbf{T}_{9}$ & 2,4-D $10 \mathrm{ppm}+\mathrm{ZnSO}_{4} 0.5 \%$ & 24.82 & 20.59 & 13.73 & 9.89 & 6.30 & 2.78 & 1.25 \\
\hline $\mathbf{T}_{10}$ & $2,4-\mathrm{D} 20 \mathrm{ppm}+\mathrm{ZnSO}_{4} 0.5 \%$ & 25.42 & 19.12 & 13.73 & 8.48 & 4.89 & 1.66 & 1.66 \\
\hline $\mathbf{T}_{11}$ & NAA 20 ppm + Borax $0.5 \%$ & 24.27 & 19.89 & 14.22 & 9.66 & 6.11 & 2.44 & 2.44 \\
\hline $\mathbf{T}_{12}$ & NAA 40 ppm + Borax $0.5 \%$ & 24.72 & 18.77 & 12.99 & 9.11 & 5.44 & 2.11 & 1.78 \\
\hline $\mathbf{T}_{13}$ & 2,4-D $10 \mathrm{ppm}+$ Borax $0.5 \%$ & 24.33 & 19.63 & 12.66 & 9.11 & 5.33 & 2.44 & 2.01 \\
\hline
\end{tabular}


Table.7 Effect of foliar spray of plant growth regulators and micronutrients (NAA, 2,4-D, Zn \& B) on fruit retention per cent at monthly intervals.

\begin{tabular}{|c|c|c|c|c|c|c|c|c|}
\hline Symbols & Treatments & $\begin{array}{c}\text { May16 } \\
(\%)\end{array}$ & June $16(\%)$ & $\begin{array}{c}\text { July } 16 \\
(\%)\end{array}$ & $\begin{array}{c}\text { Aug } 16 \\
(\%)\end{array}$ & Sept16 (\%) & Oct16 (\%) & $\begin{array}{c}\text { Nov.16 } \\
(\%)\end{array}$ \\
\hline $\mathbf{T}_{\mathbf{0}}$ & Control (water spray) & 70.51 & 77.03 & 83.08 & 89.03 & 91.81 & 92.84 & 93.56 \\
\hline $\mathbf{T}_{1}$ & NAA 20 ppm & 71.47 & 73.3 & 79.98 & 87.61 & 91.01 & 95.34 & 97.56 \\
\hline $\mathbf{T}_{2}$ & NAA 40 ppm & 72.18 & 71.85 & 77.45 & 84.52 & 92.93 & 96.37 & 97.92 \\
\hline $\mathbf{T}_{\mathbf{3}}$ & 2,4-D $10 \mathrm{ppm}$ & 74.68 & 77.71 & 83.84 & 90.56 & 93.48 & 96.78 & 98.89 \\
\hline $\mathbf{T}_{4}$ & 2,4-D $20 \mathrm{ppm}$ & 76.14 & 81.25 & 83.73 & 91.11 & 94.00 & 97.78 & 98.66 \\
\hline $\mathbf{T}_{5}$ & $\mathrm{ZnSO}_{4} 0.5 \%$ & 75.67 & 80.33 & 84.49 & 90.89 & 93.92 & 97.23 & 97.82 \\
\hline $\mathbf{T}_{6}$ & Borax $0.5 \%$ & 69.24 & 71.83 & 81.57 & 91.78 & 94.88 & 98.01 & 98.01 \\
\hline $\mathbf{T}_{7}$ & $\mathrm{NAA} 20 \mathrm{ppm}+\mathrm{ZnSO}_{4} 0.5 \%$ & 74.47 & 82.16 & 85.48 & 90.89 & 94.01 & 97.11 & 98.48 \\
\hline $\mathbf{T}_{8}$ & $\mathrm{NAA} 40 \mathrm{ppm}+\mathrm{ZnSO}_{4} 0.5 \%$ & 74.86 & 79.15 & 83.45 & 89.02 & 93.78 & 96.89 & 98.45 \\
\hline $\mathbf{T}_{\mathbf{9}}$ & 2,4-D $10 \mathrm{ppm}+\mathrm{ZnSO}_{4} 0.5 \%$ & 75.18 & 79.41 & 86.27 & 90.11 & 93.7 & 97.22 & 98.75 \\
\hline $\mathbf{T}_{10}$ & 2,4-D $20 \mathrm{ppm}+\mathrm{ZnSo}_{4} 0.5 \%$ & 74.58 & 80.88 & 86.27 & 91.52 & 95.11 & 98.34 & 98.34 \\
\hline $\mathbf{T}_{11}$ & NAA 20ppm + Borax 0.5\% & 75.73 & 80.11 & 85.78 & 90.34 & 93.89 & 97.56 & 97.56 \\
\hline $\mathbf{T}_{12}$ & NAA 40 ppm + Borax $0.5 \%$ & 75.28 & 81.23 & 87.01 & 90.89 & 94.56 & 97.89 & 98.22 \\
\hline $\mathbf{T}_{13}$ & 2,4-D $10 \mathrm{ppm}+$ Borax $0.5 \%$ & 75.67 & 80.37 & 87.34 & 90.89 & 94.67 & 97.56 & 97.99 \\
\hline \multirow[t]{3}{*}{$\mathbf{T}_{14}$} & 2,4-D $20 \mathrm{ppm}+$ Borax $0.5 \%$ & 74.73 & 77.69 & 83.89 & 88.83 & 92.89 & 96.45 & 98.12 \\
\hline & S.Em. \pm & 2.49 & 2.02 & 2.09 & 2.33 & 1.72 & 0.83 & 1.15 \\
\hline & $\mathrm{CD}$ at $5 \%$ & NS & 5.85 & NS & NS & NS & 2.40 & NS \\
\hline
\end{tabular}


The higher weight of fruit could possibly be due to better availability of nutrients influenced photosynthesis activities. The result is similar to the earlier findings obtained by Nawaz et al., (2008); Ashraf et al., (2013) in Kinnow.

Similarly, due to foliar sprays of growth regulators, micronutrients and their combinations, a significant increase in length and breadth of fruit was noted with the passage of time. The maximum length of fruit was recorded in $\mathrm{T}_{7}$ (NAA $20 \mathrm{ppm}+\mathrm{ZnSO}_{4}$ $0.5 \%)(6.66 \mathrm{~cm})$ followed by $\mathrm{T}_{1}(6.50 \mathrm{~cm})$ and $\mathrm{T}_{3}(6.46 \mathrm{~cm})$, the minimum length of fruit was recorded in $\mathrm{T}_{8}(6.10 \mathrm{~cm})$. However, the control fruit were found to be of $5.39 \mathrm{~cm}$. while all the treatments were at par with each other. A progressive increase was recorded in breadth of Kinnow fruit in subsequent months from May to November. The treatments were significant at all the date of observations in terms of breadth of fruit. The maximum breadth of fruit was recorded in $\mathrm{T}_{2},(6.85 \mathrm{~cm})$ followed by $T_{3}$ and $T_{6}$ while the minimum breadth of fruit was recorded in control $(5.69 \mathrm{~cm})$. Moreover, all the treatments were at par with each other. Similarly, among the different treatments, the maximum volume of fruit was recorded in $T_{7}(6.83 \mathrm{cc})$. The treatment $\mathrm{T}_{3}$ in terms of volume of fruit was at par to $T_{6}$ and $T_{122}$. The minimum volume of fruit was recorded in control $(5.25 \mathrm{cc})$, while all the treatments were at par to each other.

A progressive increase was recorded in volume of Kinnow fruit in subsequent months from May to November and treatment effects were significant at all the date of observations. Better fruit growth in terms of length, breadth and volume of fruit as influenced by spray of growth regulators and micronutrients, might be due to correcting the deficiencies of micronutrients and easy availability of growth promoting substances like auxins. The result is in concurrence with findings of Kaur et al.,
(2015); Bons et al., (2015) in Kinnow and Li, et al., (2016) in Shatangju mandarin.

Effect of plant growth regulators and micronutrients spray on fruit drop and retention

Foliar application of plant growth regulators and micronutrients had significantly decreased the fruit drop over control (water spray) up to August at monthly intervals and thereafter, it was non-significant. The heavy fruit drop in Kinnow was recorded during the month of May and June. There was significant influence of spray treatment A progressive decrease was recorded in drop of Kinnow fruits in subsequent months. After July month, less dropping of fruits $(\%)$ were recorded which may possibly be due to effect of treatments besides better moisture and environmental conditions. The maximum per cent drop of fruit was recorded at initial stage in control $(29.50 \%)$ and subsequently decreasing till harvest (6.44\%). The data revealed that spray treatments minimized fruit drop in Kinnow. At final stage, per cent fruit drop was almost at par among the treatments employed. However, minimum fruit drop at final stage was recorded under $\mathrm{T}_{3}(1.11 \%)$. Spray of growth regulators increased fruit retention from pea stage till harvest by controlling fruit drop.

Exogenous application of auxins treatments like NAA (20ppm+ $0.5 \%$ borax) and 2,4-D 10 $\mathrm{ppm}$ was found effective for fruit retention $(\%)$. The maximum per cent fruit retention was observed under $\mathrm{T}_{3}$ (2,4-D $\left.10 \mathrm{ppm}\right)$ followed by $T_{7}$. There was no significant difference at initial and final stage of observation recorded. Difference among treatment was significant during the month of June and October. All other treatments were at par to each other and superior to control. It may possibly be due to correcting the deficiency of micronutrients and balancing in natural hormones levels during fruit growth 
and development stages. Similar results have also reported by Singh and Mishra (1986), Ashraf et al., (2013), Nawaz et al., (2011) in Kinnow mandarin and Kumar et al., (2009) in Litchi.

The study included the application of plant growth regulators (NAA 20, $40 \mathrm{ppm}),(2,4-\mathrm{D}$ $10,20 \mathrm{ppm}$ ) and micronutrients (Zinc sulphate and Borax@0.5 per cent) and their effect on fruit growth and fruit retention in Kinnow mandarin under hot arid conditions.

Significantly higher fruit weight, length and volume of fruit was observed under $T_{7}$ treatment (20 ppm NAA+0.5\% Zn) during fruit growth at monthly intervals. However, maximum breadth of fruit was recorded under $\mathrm{T}_{2}$ (NAA $40 \mathrm{ppm}$ ). The rapid fruit growth was observed in terms of increase in weight, length, breadth and volume of fruit from May to September month. The application of growth regulators and micronutrients decreased per cent fruit drop in comparison to control (water spray) during subsequent months. The minimum fruit drop at final stage of study $(1.11 \%)$ was recorded under 2,4-D $10 \mathrm{ppm}$, while it was maximum $(6.44 \%)$ in control.

The number of days taken for maturity of fruit after spray was higher in control (179.33) and it was minimum in 20 ppm 2,4-D (170.12). At harvest, fruit weight, length and volume of fruits were significantly influenced by application of treatment $\mathrm{T}_{7}$ (NAA $20 \mathrm{ppm}$ $\left.+0.5 \% \mathrm{ZnSO}_{4}\right)$. However, maximum breadth of fruit was under $\mathrm{T}_{9}(2,4-\mathrm{D} 10 \mathrm{ppm}+0.5 \% \mathrm{Zn})$ treatment. One year experimentation, it may be concluded that lower concentration of plant growth regulators and micronutrients viz. NAA $20 \mathrm{ppm}+\mathrm{ZnSO}_{4} \quad 0.5 \%$ significantly increased plant growth, fruit growth of Kinnow plant and yield parameters under arid conditions of western Rajasthan as compared to higher concentration and control. However, these results are only indicative and require further experimentation to arrive at more consistent and final conclusion.

\section{References}

Anonymous, 2016 Kinnow cultivation in SriGanganagar. (Source: Rajasthan Patrika, Bikaner, 7.1.

Ashaf, M. Y., Asraf, M., M. Akhtar, K. Mahmud and M. Saleem,2013. Improvement in yield, and reduction in fruit drop in Kinnow (Citrus reticulata Blanco) by exogenous application of plant growth regulators, potassium and zinc. Pak. J. Bot., 45 433-440.

Bons, H. K., Harsimrat K. and Rattanpal. H. S. 2015. Quality and quantity Improvement of Citrus: Role of Plant Growth Regulators. International Journal of Agriculture, Environment and Biotechnology. 8(2): 433-447.

Bose T. K. and Mitra, S. K. 1996. Fruits in India, Naya Prakash Publication., Kolkatta, W.B.

Ibrahim, M, N. A. Abasi, Hafeezur. Rehman, z. Hussain and Hafeez.2011. Physiolcal behavior and effect of different chemicals on pre-harvest fruit drop of sweet orange cv. Salustinna. Pak. J. Bot., 443:453-457.

Kaur, N, P. K. Monga, P. K. Arora and Krishan Kumar. 2015. Effect of micronutrients on leaf composition, fruit quality and yield of Kinnow mandarin. Journal of Applied and Natural Science, 7(2): 639 - 643

Kumar, Bijay., Mistry, N. C., Singh, Brajendra and Gandhi, C.P. 2009. Indian Horticulture Database- 2009. Natl. Hort. Board, Ministry of Agri. Govt. of India, Gurgaon, pp-49

Li, J., Liang, C. H., Liu, X. Y., Huai, B., Chen, J.Z., Yao, Q., Qin, Y., Liu, Z. and Luo, X.Y. 2016. Effect of $\mathrm{Zn}$ and NAA co-treatment on the occurrence 
of creasing fruit and the peel development of 'Shatangju' mandarin. Sci Hortic, 201: 230-237.

Nawaz, A.; Waqar, A. and Khan, S. 2008. Role of growth regulators on pre harvest fruit drop, yield and quality in Kinnow mandarin. Pakistan-Journal of Botany. 40(5): 1971-1981.

Nawaz, M. A., Ahmad, W., Ahmad, S., and Khan, M. M., 2008. Role of growth regulators on preharvest fruit drop, yield and quality in Kinnow mandarin. Pakistan J. Bot., 40(5): 1971-1981.

Nawaz, M. A., Ahmad, W., Ahmad, S., and Khan, M. M., 2011. Exogenous application of 2,4-D, $\mathrm{GA}_{3}$ and NAA at flowering improves yield and quality of Kinnow mandarin (Citrus reticulate Blanco). Asian journal of plant Science and Biotechnology. Pp 1-115

Rodriguez, V. A., Mazza, S. M., Martiinez, G. C., and Ferreso, A. R. 2005. Zink and $\mathrm{K}$ influence in fruit sizes of Valencia orange. Revista- Brasileira- daefruiticultura, 27(1):132-135.

Singh, S. B. and Mishra, R. S. 1986. Effect of plant growth regulators and micronutrients on fruit drop, size and quality of Kinnow orange. Prog. Hort. 18(3-4): 260-264.

\section{How to cite this article:}

Upendar Kumar Bagri, R. S. Singh, Manju Verma, Vimal Nagar and Yadav, P. K. 2021. Effect of Plant Growth Regulators and Micronutrients on Fruit Growth Characters of Kinnow Mandarin (Citrus reticulata Blanco). Int.J.Curr.Microbiol.App.Sci. 10(04): 198-211. doi: https://doi.org/10.20546/ijcmas.2021.1004.019 